\title{
Terrorism Eradication in ASEAN Countries: Human Rights Perspective
}

\author{
Satria Unggul Wicaksana Prakasa \\ Faculty of Law, University of Muhammadiyah Surabaya, Indonesia \\ email: satria@fh.um-surabaya.ac.id \\ Sholahuddin Al-Fatih \\ Faculty of Law, University of Muhammadiyah Malang, Indonesia \\ email: sholahuddin.alfath@gmail.com \\ Abdurrahman Raden Aji Haqqi \\ Faculty of Sharia and Law, Universiti Islam Sultan Sharif Ali (UNISSA), \\ Brunei Darussalam \\ email:abdurrahman.haqqi@unissa.edu.bn
}

Article history: Received: August 24, 2021, Accepted: December 23, 2021, Published: December 31, 2021

\begin{abstract}
:
This research aims to discuss ASEAN counter-terrorism policy and its impact on human rights protection. The terrorism act of Abu Sayyaf in the Philippines, the spread of terrorism in Indonesia by JAT and JAD, and the rebellion movement in Pattani-Thailand are the most heard of terrorism cases in Southeast Asian countries. The research focused on the regulatory through comparative approaches. The result found that ASEAN has an agreement known as ASEAN Convention on Counter-Terrorism (ACCT) for combating terrorism. ACCT implementation in national legal regulations of ASEAN members in the midst of the spread of terrorism plays a crucial role in combating terrorism and its impact on human rights protection. However, the effort of eradicating terrorism in Southeast Asian countries is not in line with the principles of peace and regional integrity. The practice of authoritarianism and militarism has instead become most prominent as a result
\end{abstract}

Author correspondence email: satria@fh.um-surabaya.ac.id Available online at: http:/ / ejournal.iainmadura.ac.id/index.php/alihkam/ Copyright (c) 2021 by al-ihkam. All Right Reserved 
Satria Unggul Wicaksana Prakasa, Sholahuddin Al-Fatih, Abdurrahman Raden Aji Haqqi

of perpetuating militarism-based legal regulations in resolving terrorism. Efforts for combating terrorism in Southeast Asia, therefore, leave a serious problem regarding the protection of human rights, the issue of impunity, attacks on civil society, and the involvement of the military which threatens territorial integrity. Those are at cross purposes with ACCT policies as well as national sovereignty, integrity, and security of ASEAN members.

\title{
Keywords:
}

ASEAN; Counter-Terrorism; Human Rights; Southeast Asia

\begin{abstract}
Abstrak:
Penelitian ini bertujuan membahas kebijakan anti-terorisme ASEAN dan dampaknya terhadap perlindungan hak asasi manusia. Aksi terorisme Abu Sayyaf di Filipina, penyebaran terorisme di Indonesia oleh JAT dan JAD, serta pemberontakan di Pattani-Thailand adalah kasus-kasus terorisme terpopuler yang terjadi di Asia Tenggara. Penelitian ini fokus pada peraturan perundang-undangan dengan pendekatan komparatif. Hasilnya menunjukkan bahwa ASEAN memiliki kesepakatan yang disebut Konvensi ASEAN tentang KontraTerorisme (ACCT) untuk memerangi terorisme. Penerapan ACCT dalam peraturan hukum nasional negara anggota ASEAN di tengah maraknya aksi terorisme sangat penting dalam upaya pemberantasan terorisme dan dampaknya terhadap perlindungan hak asasi manusia di ASEAN. Akan tetapi dalam praktiknya, pemberantasan terorisme di ASEAN masih belum sejalan dengan prinsip perdamaian dan keutuhan kawasan. Praktik otoritarianisme dan militerisme justru menjadi praktik paling menonjol yang dilakukan oleh negaranegara di ASEAN seiring dengan langgengnya regulasi hukum berbasis praktik militerisme dalam menyelesaikan kejahatan terorisme. Pemberantasan terorisme di Asia Tenggara menyisakan masalah serius terkait perlindungan hak asasi manusia, isu impunitas, serangan terhadap masyarakat sipil, dan keterlibatan militer yang mengancam integritas teritorial. Isu-isu tersebut bertentangan dengan Kebijakan ACCT serta kedaulatan, integritas nasional, dan keamanan anggota ASEAN.
\end{abstract}


Kata Kunci:

ASEAN; Pemberantasan Terorisme; Hak Asasi Manusia; Asia Tenggara

\section{Introduction}

As a dynamic region, Southeast Asia faces various political and security issues. The area is particularly facing a significant problem related to trans-border terrorist crimes. Since 2016, triggered by the operation of the Islamic States of Iraq and Syria (ISIS) network, regional security has worsened. The Abu Sayyaf network in the Philippines, the Pattani terrorism network in Southern Thailand, and the ISIS network through Jama'ah Ansorul Daulah (JAD) and Jama'ah Ansorul Tauhid (JAT) in Indonesia indicate a more critical spread of terrorism network and pose a threat at the regional level. ${ }^{1}$

Additionally, the spread of the ISIS network across several regions in Southeast Asia has departed from various motives and backgrounds ranging from causing threats and national riots to instability. The group furthermore attempts to separate themselves from their native countries. For example, in the Philippines, the Moro Islamic Liberation Front (MILF) and the Abu Sayyaf terrorist group want to create an Islamic state separated from the Philippines in the southern province of Mindanao. It has become an insurgent group and has carried out numerous terrorism activities. Since the 1990s, the group had launched several attacks, including the significant attacks in February $2005^{2}$ and new attacks emerging in 2016 and 2017.

The terrorism movement in Southern Thailand (Narathiwat, Pattani, and Yala Provinces), meanwhile, took place in 2003. It has overgrown and turned into a massive rebellion. Additionally, the terrorist groups namely PULO (Pattani United Liberation Organization) and Bersatu (Barisan Kemerdekaan Pattani/United Front for the Independence of Pattani) with direct links with Al-Qaeda key

1 Marguerite Borelli, “ASEAN Counter - Terrorism Weaknesses," International Centre for Political Violence and Terrorism Research 9, no. 9 (2017): 14-20, https://www.jstor.org/stable/pdf/26351552.pdf?refreqid=excelsior\%3A4b7501f4cc5 772d930ea229e7b1c942d. 15.

2 Jonathan T. Chow, "ASEAN Counterterrorism Cooperation Since 9/11," Asian Survey 45, no. 2 (2005), https://doi.org/https://doi.org/10.1525/as.2005.45.2.302. 303 
persons such as Omar al-Farouk and Commander Ali Gufron ${ }^{3}$ had performed various terrorism acts and thus posing a big threat to regional stability.

Meantime, the terrorism movement in Indonesia also needs to be taken seriously as an alarming trend threatening regional stability. Bali bombing 1 and 2, bombings in Australian Embassy, the Ritz Charlton, Poso, and the bombing recently happening in Surabaya and Sidoarjo last 2018 are some cases worrying the country. Most recently, the repatriation of ISIS Foreign Terrorism Fighters (FTF) from Indonesian citizens sparks marked pros and cons. About 6 Indonesians who joined FTF in Syria, such as Al-Roj, Al-Hol, and Ainisa camps expected to return to Indonesia. The Indonesian government's official statement based on a special Cabinet meeting $(11 / 2 / 2020)$ stated that they did not plan to repatriate the FTF to

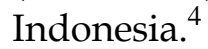

This stems response of ASEAN (Association of Southeast Asian Nations) as a regional organization in Southeast Asia that focuses on cooperation among member countries to create regional security and stability. For instance, one of ASEAN's commitments is stated in the ASEAN Political and Security Community (APSC) and set forth in the Charter of ASEAN as the constitutive charter of Southeast Asian countries. As a concrete averment of the ASEAN cooperation, ASEAN members regularly gather on the ASEAN Regional Forum (ARF) agenda, a regional meeting to discuss regional issues, including terrorism. ${ }^{5}$

Moreover, as a derivative of the ASEAN Charter and in the context of realizing the APSC, maintaining peace, security, and regional stability as well as realizing cooperative action or engagement among countries, ASEAN member countries agreed to form the ASEAN Convention on Counter-Terrorism (ACCT). ACCT was established in Cebu, Philippines, on January 13, 2007. This legal basis is evidence for the ASEAN community's agreement on the status

3 Kavi Chongkittavorn, "Thailand: International Terrorism and the Muslim South," Southeast Asian Affairs, 2004, 267-75.

4 CNN Indonesia, "Pemerintah Putuskan Tak Akan Pulangkan 689 WNI Eks ISIS. Retrieved from CNN Indonesia," CNN Indonesia, 2020.

5 Juurgen Haacke and Noel M. Morada, Cooperative Security in the Asia-Pacific: The ASEAN Regional Forum (New York: Routledge, 2010). 25 
of terrorism as an extraordinary crime. Simultaneously, a tremendous potential threat to regional sovereignty and security was getting more prominent due to terrorism crimes. ${ }^{6}$

On the other hand, there are several challenges to deal with in order to create regional political and security integration, particularly concerning with prevention of increasing intensity of terrorism. The challenges mainly come from the political stance of each member country who potentially do one of the following: ${ }^{7}$

a. Refraining from criticizing any fellow countries related to various domestic problems policies, including those related to human rights violations;

b. Criticizing any actions of fellow countries as a part of the intervention.

c. Refusing recognition and sanction while supporting neighboring rebel groups.

d. Providing political support and assistance for campaigns against national sovereignty

Therefore, ASEAN member countries' efforts should be made as an international political stance to overcome terrorism considering that so far, they have been limited and ineffective in countering terrorism or maintaining regional security. ASEAN member countries need thoughtful and effective steps to tackle terrorism and to protect human rights for their community. ${ }^{8}$

This research has a significant scientific contribution to upholding human rights through efforts in combating terrorism in Southeast Asia. More specifically, this research focuses on how terrorism eradication is supposed to follow legal and regulatory

\footnotetext{
${ }^{6}$ A. Masuhara, The SAGE Handbook of Asian Foreign Policy, ed. Takeshi Inoguchi (California: SAGE Publications, 2020), https://doi.org/10.4135/9781526436078.n54. 113

7 L Jones, ASEAN, Sovereignty, and Intervention in Southeast Asia (London: Palgrave Macmillan, 2011), https:/ / books.google.co.id/books?hl=id\&lr=\&id=DbKIGm7x64kC\&oi=fnd\&pg=PP1 \&dq=Jones,+L.+(2012).+ASEAN,+Sovereignty,+and+Intervention+in+Southeast+Asi a.+London:+Palgrave+MacMillan\&ots=Cr4M8e9lp-\&sig=kCdXruKIq4FA8q4qKPLFPPy86A\&redir_esc $=y \# v=$ onepage\&q=Jones $\% 252.45$

8 Andrew Chau, "Security Community and Southeast Asia: Australia, the U.S., and ASEAN's Counter-Terror Strategy," Asian Survey 48, no. 4 (2008): 626-649, https://doi.org/10.1525/as.2008.48.4.626. 630
} 
standards as well as the appreciation of human rights. ${ }^{9}$ It will furthermore help the scientific development of international humanitarian law, human rights law, and law on criminal acts of terrorism. Conceptually, the aim is to draw a comprehensive picture of how to overcome terrorism crimes in Southeast Asia through ASEAN's power as a regional organization and mutually beneficial cooperation for its member countries.

\section{Method}

The research focused on regulatory through a comparative approach. This is mainly because several countries in Southeast Asia have implemented counter-terrorism policies to fight against terrorism. Meanwhile, the method used to discuss terrorism eradication needs to analyze the operation of terrorist groups using several methods, including analysis of existing information. ${ }^{10}$

Electronic data were comprehensively collected to find out how dangerous the ideological doctrine of the terrorist network is. The data encompasses strategy formulation and terrorist attacks history records, including the form of bomb attacks, cyber attacks, and other armed attacks. With the nature of this research, its topic on terrorism deals with an approach to literature. ${ }^{11}$

\section{Discussion and Result}

\section{Terrorist Groups and Their Liability for the Law}

The suppression of criminal acts of terrorism has always been targeting terrorist groups. A terrorist group is defined as a group of individuals with an awareness of their ideology and willingness to be trained, to budge (as FTF), and to act as combatants in the committed acts of terrorism. The consequences of individuals who are considered a part of a terrorist group network involve the prohibition of going

9 Irwansyah, Penelitian Hukum: Pilihan Metode \& Praktik Penulisan Artikel, ed. Ahsan Yunus (Yogyakarta: Mirra Buana Media, 2020). 95

10 A. Basu, "Social Network Analysis: A Methodology for Studying Terrorism," in Intelligent Systems Reference Library, vol. 65 (Basel: Springer Nature, 2014), 215-42.

11 A. P. Schmid, "The Literature on Terrorism," in The Routledge Handbook of Terrorism Research (New York: Routledge, 2011), 460-62. 
abroad, temporary confiscation of assets, and being included in red immigration records. ${ }^{12}$

The latest development in non-international armed conflict has responded to the times. It is the pressure from the international community to immediately enact counter-terrorism policies globally. This pattern is the same as the UN resolutions made after the 9/11 WTC bombing that staggered the international community. Allegedly, Osama bin Laden, Al-Qaeda, and Taliban networks who are expanding and developing rapidly in Iraq, Afghanistan, and Pakistan, were the perpetrators of the incident. Similarly, Israeli attacks on opposition factions in Palestine are often categorized as Hamas' terrorists, the same way with the terrorist group in Lebanon, Hezbollah. Until recently, terrorism networks based in Iraq and Syria, which today are the foremost executants, continue to grow. Islamic States of Ira and Syria (ISIS), meanwhile, have become non-state actors who have either conflict with their native country or commit terrorist attacks in other countries. ${ }^{13}$ Therefore, the presence of FTF has become a distinctive and substantial issue globally.

The interpretation of the war on terror by the United States is likely a landmark decision for the war on terrorism, where the extraterritorial principle was carried out to find the perpetrators of 9/11. The US invasion of Afghanistan and Iraq has killed approximately 700,000 innocent civilians and destroyed infrastructure such as civil

12 K. Roach, Comparative Counter-Terrorism Law (New York: Cambridge University Press, 2015). 78

13 Derek Jins and Jackson N. Maogoto, Applying International Humanitarian Law in Judicial and Quasi-Judicial Bodies: International and Domestic Aspects, ed. Solon Solomon (Springer, 2014), https:/ / books.google.co.id/books?hl=id\&lr=\&id=8fosBAAAQBAJ\&oi=fnd\&pg=PP5 $\& d q=$ Derek+Jins, + e.+(2008).+Applying+International+Humanitarian+Law+in+Judici al+and+Quasi-

Judicial+Bodie\%3B+International+and+domestic+aspect.+London:+Springer.\&ots=2 GY9Zlh3hK\&sig=rGP6. 234 
and historical buildings. The invasion causes a bad precedent for international humanitarian law. ${ }^{14}$

Therefore, there needs to be a mechanism for recognizing and accounting for terrorism from parties involved in a non-international armed conflict based on international humanitarian law mechanisms. A more comprehensive mechanism and approach in eradicating terrorism need to be made upon human values. With that realization, innocent civilians will no longer be the victims of invasion and war. International security is the mandate of the international legal mechanisms under the United Nations resolutions. ${ }^{15}$

The United Nations, through the General Assembly and Security Council, has drafted international legal regulations derived from mechanisms intended to tackle terrorism. Moreover, the UN also promotes the protection of human rights while recognizing terrorism as an international crime followed by principles of protection for refugees who are the victims of terrorism in the UN General Assembly resolution 60/1, agreed on September 20, 2005. ${ }^{16}$ Also, Global Counter-Terrorism Strategy is ratified on September 8, 2006. ${ }^{17}$

Counter-terrorism strategy in the pillars compiled by the United Nations related to terrorism eradication encompasses: (Pillar I) - the counter of terrorism that spreads throughout the world. (Pillar II) - the prevention and eradication of terrorism crimes, (Pillar III) -

14 Roberta Arnold and Noelle Quenivet, International Humanitarian Law and Human Rights Law: Towards a New Merger in International Law (Leiden and Boston: Martinus Nijhoff Publisher, 2008). 88

15 Ana María Salinas de Frías, Katja Samuel, and Nigel White, Counter-Terrorism: International Law and Practice (Oxford: Oxford University Press, 2012), https:// books.google.co.id/books?hl=id\&lr=\&id=mhC7TNrTGmcC\&oi=fnd\&pg=PP $1 \& d q=$ Nigel+D.+White, + e. $+(2012) .+$ Counter -

Terrorism:+International+Law+and+Practice.+Oxford:+Oxford+University+Press.\&o ts=DUQGBEL00K\&sig=Oh7MYPm239TK9nn4b1CQ0UpSFRY\&redir_esc=y\#v=onepa ge. 43

16 United Nations, “UN Doc A/RES/60/1” (2005).

17 United Nations, “UNGA Res 60/288” (2006). 
constructing the state's capacity in strengthening the role of combating terrorism under the UN mechanism; (Pillar IV) - the guarantee of protection of human rights and rules of law. ${ }^{18}$ In this case, the method of combating global terrorism must be carried out in line with international humanitarian law's objectives. The tactical attacks aimed to take down terrorism must uphold human rights values, respect legal principles, and protect civil society both at the regional and global levels so that terrorism can be handled properly and thoroughly.

\section{ASEAN's Role to Conduct Counter-Terrorism Policy}

As a response to terrorist actions in the ASEAN region, the ACCT was signed in 2007 then ratified by 6 ASEAN member countries in 2011. Only in 2013, all ASEAN member countries finally ratified the ACCT. ${ }^{19}$ As a regional legal instrument in combating terrorism, ACCT has the scope and recognition of terrorism types that are growing globally. In Article II, ACCT states that the types of recognized terrorism crimes are: (a) Crimes of terrorism and their relation to aircraft hijacking; (b). Terrorism and attacks on foreign diplomats; (c). Terrorism and prisoner protection; (d). Terrorism and the use of treacherous nuclear weapons; (e). Safety protocols on civil aviation; (f). Terrorism crimes that disrupt international shipping; (g). Terrorism crimes and the emphasis on bombers; (h). Terrorism crime financing.

However, a specific issue makes it difficult for the ACCT to integrate into the actions against terrorism in the region, namely points substantiated in Article III-IV of the ACCT. It explains that

18 María Jiménez Ramos, "The Impact of the Narrative of Victimization: An Experiment with University Students in Spain," Behavioral Sciences of Terrorism and $\begin{array}{lllll}\text { Political Aggression } 0, & \text { no. } & 0 & \text { (2020): }\end{array}$ https://doi.org/10.1080/19434472.2020.1856168. 20

19 Borelli, “ASEAN Counter - Terrorism Weaknesses.” 3 
fellow countries are obliged to respect other country's sovereignty. Consequently, the exclusivity of law enforcement related to the prosecution of terrorism crimes has hampered ASEAN's steps in the eradication process. In Article $\mathrm{V}$, furthermore, ACCT only focuses on preventing terrorism crimes as described in Article II ACCT.

Article $\mathrm{V}$ of the ACCT highlights how member countries strengthen global or cross-border cooperation considering a chance of terrorism activities in the point-like those committed by the Abu Sayyaf group. Through the series of terrorism acts, the group moved to the Sulu border location/Mindanao. Along with it, Sulawesi became a very strategic area for transit points, war logistics and weapons administration, and a base for the attack objects. Another significant attack was also committed by Abu Sayyaf group in midSeptember 2013 and about 30,000 civilian prisoners were captured. This is not only a trouble for the Philippines, but also a regional problem since some fishermen from other countries also became hostages. ${ }^{20}$ Those obvious matters do not only, therefore, require cooperative action, but also an establishment and placement of armed alliance.

The paradox of maintaining state exclusivity in dealing with terrorism on the pretext of sovereignty in Southeast Asia has presented an obstacle. It has made regional terrorism activities intensified. In addition to forming a defense alliance, ASEAN member countries need to get integrated into a specific criminal law and set regional jurisdiction for terrorism. This is necessary to be addressed

20 Senia Febrica, "Securing the Sulu-Sulawesi Seas from Maritime Terrorism : A Troublesome Cooperation?," Perspectives on Terrorism 8, no. 3 (2014): 64-83, https://www.jstor.org/stable/26297173?seq=1\#metadata_info_tab_contents. 68 
because the impact of terrorism creates a worrying regional instability. ${ }^{21}$

To strengthen commitment in eradicating terrorism crimes in the region, raising awareness is needed to integrate criminal policies. Additionally, it needs unification of criminal acts of terrorism before the court and law enforcement officials among member countries that exceed the jurisdiction of each state or beyond each's national jurisdiction. $^{22}$

\section{Deradicalization Practices in ASEAN}

Deradicalization is the primary strategy in eradicating terrorism. It is a strategic step that a country can take to fight terrorism. Deradicalization relates closely to religious beliefs. Cognitive knowledge that both individuals and groups believe is justified in the activities of terrorism and violence. Additionally, the common perspectives of moderate peace and education are critical factors in efforts of deradicalization. However, it should be supported by strong policies so that deradicalization efforts can be realized, especially in Muslim countries with a great potential for radicalism. ${ }^{23}$ For terrorism suspects, efforts to rehabilitate their radicalism within the prison scope are an effective strategy because it is right on the target. Besides, law enforcement for terrorism networks performed by

21 Sandy Gordon, "Regionalism and Cross-Border Cooperation against Crime and Terrorism in the Asia-Pacific," Security Challenges 5, no. 4 (2009): 75-102, https://www.jstor.org/stable/26460070?seq=1\#metadata_info_tab_contents. 85

22 Satria Unggul Wicaksana Prakasa, Basuki Babussalam, and Agus Supriyo, "Transnational Corruption and Its Impact on Indonesian Jurisdiction," in 2nd International Conference of Law, Government and Social Justice (ICOLGAS 2020) (Atlantis Press, 2020), 43-53, https:/ / doi.org/10.2991/assehr.k.201209.266. 46

23 Sulistiyono Susilo and Reza Pahlevi Dalimunthe, "Moderate Southeast Asian Islamic Education as a Parent Culture in Deradicalization: Urgencies, Strategies, and Challenges," Religions 10, no. 1 (2019), https:/ / doi.org/10.3390/ rel10010045. p. 31 
the authorities is another effective effort to prevent the widespread terrorist radicalization network in the future. ${ }^{24}$

Various rehabilitation efforts in the deradicalization agenda for terrorist groups aim at eliminating the paradigm of violence justification that the groups believe. By equating perception and paradigm, further strategies for deradicalization can be implemented easily. Besides, amnesty efforts can also be given by the state as compensation for terrorist convicts who undergo the deradicalization program. These strategies will attest to terrorism networks, terrorism financing, doctrine models, and law enforcers as a strategy for eradicating terrorism in a country. Besides, with a social interaction approach, state repression diminution, and charismatic methods, jihadist groups will be fully aware that they perform delegitimizing actions for the violence they committed before. ${ }^{25}$

\section{ASEAN Countries' Best Practice to Counter Terrorism}

Although the ACCT has become a legal instrument in combating terrorism in the ASEAN region, its requisite power and implementation in each ASEAN member country vary. This depends on the legal politics of terrorism eradication policies in each ASEAN member countries. The following table shows the comparison of the

\footnotetext{
24 Jolene Jerard et al., Deradicalisation and Terrorist Rehabilitation : A Framework for Policy-Making and Implementation, ed. Rohan Gunaratna and Sabariah Hussin (Taylor \& Francis, 2018), https:/ / books.google.co.id/books?hl=id\&lr=\&id=7U9tDwAAQBAJ\&oi=fnd\&pg=PT $16 \& d q=$ Rohan+Gunaratna,+and+Sabariah+Hussin+(ed),+Deradicalisation+and+Terr orist+Rehabilitation+:+A+Framework+for+Policy-

Making+and+Implementation,+Taylor+\%26+Francis+Group,+2018.+ProQu. 143

25 Omar Ashour, The De-Radicalization of Jihadists: Transforming Armed Islamist Movements, 1st ed. (London: Routledge, 2009), https:/ / books.google.co.id/books?hl=id\&lr=\&id=h6pTaBDybKAC\&oi=fnd\&pg=PP1 $\& d q=$ Ashour,+ O.+(2009).+The+De-

Radicalization+of+Jihadists:+Transforming+Armed+Islamist+Movements+(1st+ed.). +Routledge\&ots=W9r2SjF2v2\&sig=NuhX1bzOPZoTLu6iPSAEU0jjBkQ\&redir_esc=y\# $\mathrm{v}=$ onep. 231
} 
application of the ACCT and the national laws of each ASEAN member country in combating terrorism:

Table 1. Practices of ASEAN Countries in Combating

Terrorism 2627282930313233343536

\begin{tabular}{|c|c|c|c|}
\hline Nation & $\begin{array}{c}\text { Terrorism } \\
\text { Organization }\end{array}$ & Terrorism Acts & $\begin{array}{l}\text { Anti-Terrorism Law } \\
\text { Enforcement }\end{array}$ \\
\hline $\begin{array}{l}\text { Indonesia } \\
\text { (BNPT and } \\
\text { Densus 88) }\end{array}$ & 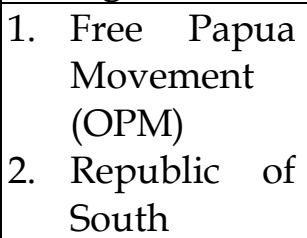 & $\begin{array}{l}\text { Bali Bombing I, } \\
\text { Bali Bombing II, } \\
\text { Bombing at the } \\
\text { Malaysian } \\
\text { Embassy, Bombing }\end{array}$ & $\begin{array}{l}\text { In } 2018 \text {, Densus } 88 \text { arrested } \\
\text { people unlawfully. This } \\
\text { wrongly targetting arrest } \\
\text { was experienced by Arifin, } \\
\text { a resident of Malang, who }\end{array}$ \\
\hline
\end{tabular}

\footnotetext{
${ }^{26}$ Borelli, "ASEAN Counter - Terrorism Weaknesses." 4

27 Leonard C. Sebastian, "The ASEAN Respond to Terrorism," UNISCI Discussion $\begin{array}{lllll}\text { PapersSCI Discussion Paper } & 2 & \text { (2003): }\end{array}$ https://www.redalyc.org/pdf/767/76711296010.pdf. 5

28 Sholahuddin Al-Fatih and Zaka Firma Aditya, "The Legal Protection Against Terrorism Suspects In Indonesia (Case Study of The Arrest Process of Terrorism Suspects By Densus 88)," Legality: Jurnal Ilmiah Hukum 27, no. 1 (2019): 14-26, https://doi.org/10.22219/jihl.v27i1.8954. 21

29 AA Bagus Surya Widya Nugraha, "Singapura Dan Permasalahan Terorisme" (Denpasar, 2018), http://erepo.unud.ac.id/id/eprint/21968/1/258d9fcbf781b6af3cf5bfb9b1fcdce5.pdf. 33

30 Stefanie Kam, "LAOS," in Handbook of Terrorism in the Asia-Pacific (Singapore: Nanyang Technological University, 2016), 71-84, https://doi.org/10.1142/9781783269969_0004. 74

31 Alfianti Dwi Rachma, "Perbandingan Hukum Pidana Terhadap Kejahatan Terorisme Di Indonesia Dan Filipina" (Universitas Pancasakti Tegal, 2020). p. 23

32 Aditya Putra and Diana Lukitasari, "Perbandingan Pengaturan Tindak Pidana Terorisme Di Indonesia Dan Malaysia," Recidivie 8, no. 1 (2019): 1-12, https://jurnal.uns.ac.id/recidive/article/view/40611. 5

33 Ibid. Putra and Lukitasari.

34 ICG, "Jihadism in Southern Thailand: A Phantom Menace," International Crisis Group, 2017, https://www.crisisgroup.org/asia/south-east-asia/thailand/291jihadism-southern-thailand-phantom-menace.

35 (BUREAU OF COUNTER-TERRORISM, 2020)

36 Reuters Staff, “Vietnam Jails 20 for Terrorism over Police Station Bombs," Reuters, 2020.
} 


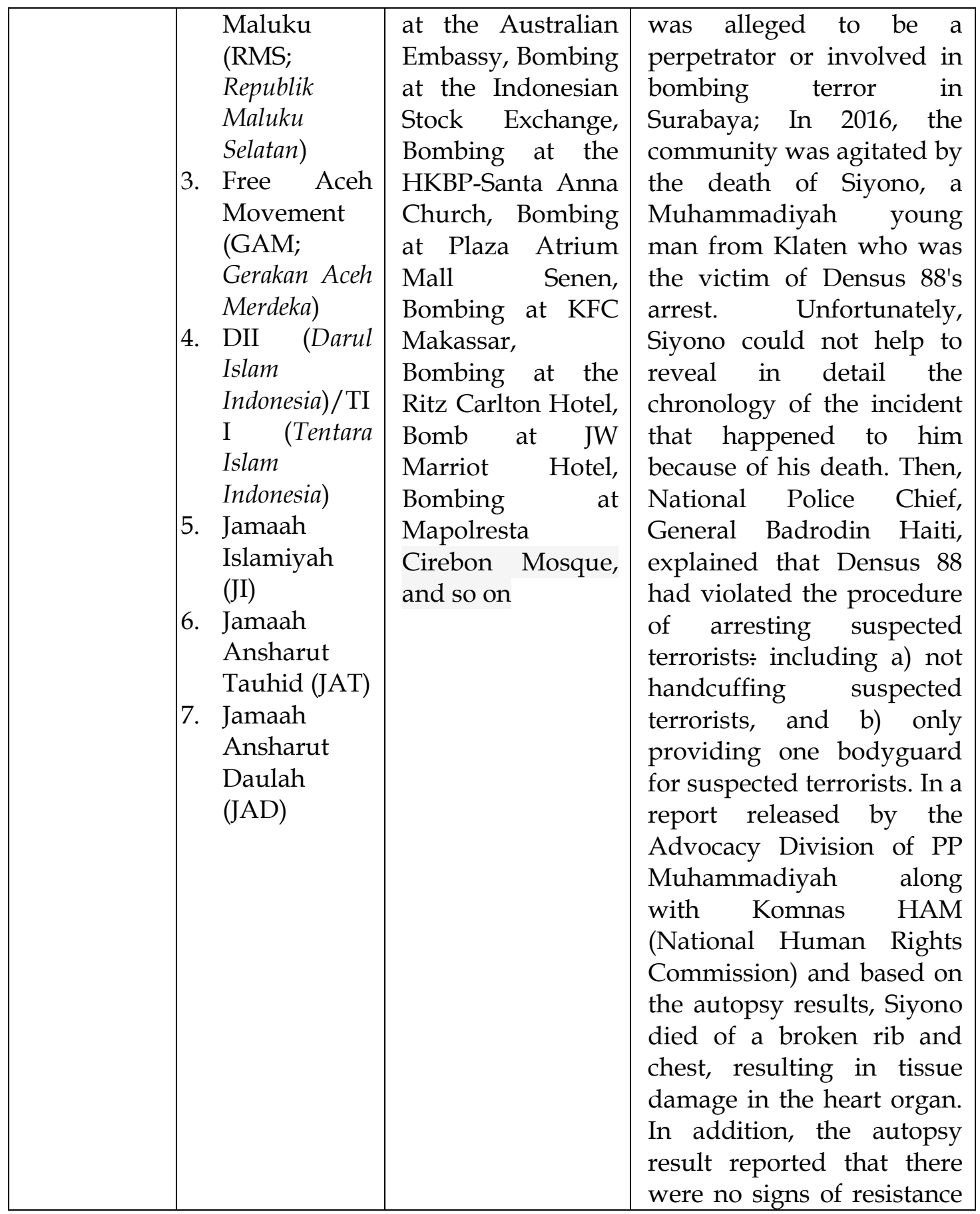




\begin{tabular}{|c|c|c|c|}
\hline & & & $\begin{array}{l}\text { from Siyono regarding the } \\
\text { bruises around the wrist. } \\
\text { This proof does not } \\
\text { correspond to the statement } \\
\text { of the National Police } \\
\text { Headquarters stating that } \\
\text { Siyono was fighting against } \\
\text { it. c). Another arrest took } \\
\text { place on Tuesday } \\
\text { (12/29/2015) in Solo, } \\
\text { Central Java. Two Solo } \\
\text { residents, Ayom Penggalih } \\
\text { and Nur Syafruddin, were } \\
\text { on their way to the mosque } \\
\text { when they were arrested by } \\
\text { Densus } 88, \text { and it was } \\
\text { found out that they were } \\
\text { not terrorists. d). In mid- } \\
\text { May 2014, Densus } 88 \text { made } \\
\text { a wrongful accusation in } \\
\text { Solo involving the arrest of } \\
\text { Kadir from Banyu Harjo } \\
\text { Village. e). Another similar } \\
\text { case took place at the end } \\
\text { of July 2013. Densus } 88 \text { also } \\
\text { arrested two } \\
\text { Muhammadiyah residents, } \\
\text { who were finally released } \\
\text { because they were later } \\
\text { proven innocent. f). Other } \\
\text { arrests against } 14 \text { Poso } \\
\text { residents followed in } 2012 \text {, } \\
\text { but the arrested were } \\
\text { proven to have no } \\
\text { involvement and were } \\
\text { released. }\end{array}$ \\
\hline $\begin{array}{l}\text { Singapore } \\
\text { (NSCS and }\end{array}$ & $\begin{array}{l}\text { Singapore } \\
\text { Jamaah }\end{array}$ & $\begin{array}{l}\text { Bombing at McD } \\
\text { in } 1965, \text { bombing }\end{array}$ & $\begin{array}{l}\text { In 2001, ISD Singapore } \\
\text { arrested } 15 \text { people, } 13 \text { of }\end{array}$ \\
\hline
\end{tabular}




\begin{tabular}{|c|c|c|c|}
\hline $\begin{array}{l}\text { ISD } \\
\text { Singapura) }\end{array}$ & $\begin{array}{l}\text { (affiliation of } \\
\text { Jamaah } \\
\text { Islamiyah) }\end{array}$ & $\begin{array}{l}\text { at the Shell oil } \\
\text { refinery complex } \\
\text { on Bukom Island, } \\
\text { the hijacking of } \\
\text { Singapore Airline } \\
\text { Flight } 117 \text { in } \\
\text { 1991, and others. }\end{array}$ & $\begin{array}{l}\text { whom were JI members. } \\
\text { In August 2002, ISD } \\
\text { recaptured } 21 \text { people, } \\
\text { nineteen of whom were JI } \\
\text { members under military } \\
\text { training with China and } \\
\text { the United States, as well } \\
\text { as deradicalizing clerical } \\
\text { Muslims by empowering } \\
\text { the potentials of Muslims. }\end{array}$ \\
\hline $\begin{array}{l}\text { Malaysia } \\
\text { (Pasgeras) }\end{array}$ & $\begin{array}{l}\text { 1. Al-Maunah } \\
\text { Movement } \\
\text { 2. Malaysian } \\
\text { Mujahidin } \\
\text { Group } \\
\text { 3. Malaysian } \\
\text { Militants } \\
\text { Group }\end{array}$ & $\begin{array}{l}\text { The hijacking of } \\
\text { Malaysia Airlines } \\
\text { Flight } 653 \text { and } \\
\text { the hijacking of } \\
\text { Malaysia Airlines } \\
\text { Flight MH370. }\end{array}$ & $\begin{array}{l}\text { The government provides } \\
\text { deradicalization efforts } \\
\text { for terrorist perpetrators } \\
\text { or suspected terrorists. } \\
\text { Deradicalization is carried } \\
\text { out with the Human } \\
\text { Development Program to } \\
\text { eliminate the radical } \\
\text { doctrine of terrorists as } \\
\text { well as to train their social } \\
\text { skills so that they have } \\
\text { provisions to re-socialize } \\
\text { with the community }\end{array}$ \\
\hline $\begin{array}{l}\text { Brunei } \\
\text { Darussalam } \\
\text { (Internal } \\
\text { Security } \\
\text { Department } \\
\text { ) }\end{array}$ & Not yet found & $\begin{array}{l}\text { Terrorism act in } \\
\text { Brunei } \\
\text { Darussalam has } \\
\text { been reportedly } \\
\text { never happened. } \\
\text { However, the } \\
\text { Brunei } \\
\text { Darussalam } \\
\text { government was } \\
\text { recorded to have } \\
\text { deported } \\
\text { Indonesian } \\
\text { citizens } \\
\text { were suspected } \\
\text { of being affiliated }\end{array}$ & $\begin{array}{l}\text { Brunei Darussalam is } \\
\text { relatively safe from any } \\
\text { terrorist acts even though } \\
\text { it is close to Malaysia, } \\
\text { Indonesia, and the } \\
\text { Philippines, in which } \\
\text { many terrors incidentally } \\
\text { have occurred. To prevent } \\
\text { terrorism, the Brunei } \\
\text { government has made } \\
\text { regulations outlining } \\
\text { preventive measures. }\end{array}$ \\
\hline
\end{tabular}




\begin{tabular}{|c|c|c|c|}
\hline & & with ISIS. & \\
\hline $\begin{array}{l}\text { Thailand } \\
\text { (Hanuman) }\end{array}$ & $\begin{array}{l}\text { 1. Thailand } \\
\text { Pattani } \\
\text { United } \\
\text { Liberation } \\
\text { Organizatio } \\
\mathrm{n} \\
\text { 2. Pattani } \\
\text { Malay } \\
\text { National } \\
\text { Revolution } \\
\text { Line (BRN) }\end{array}$ & 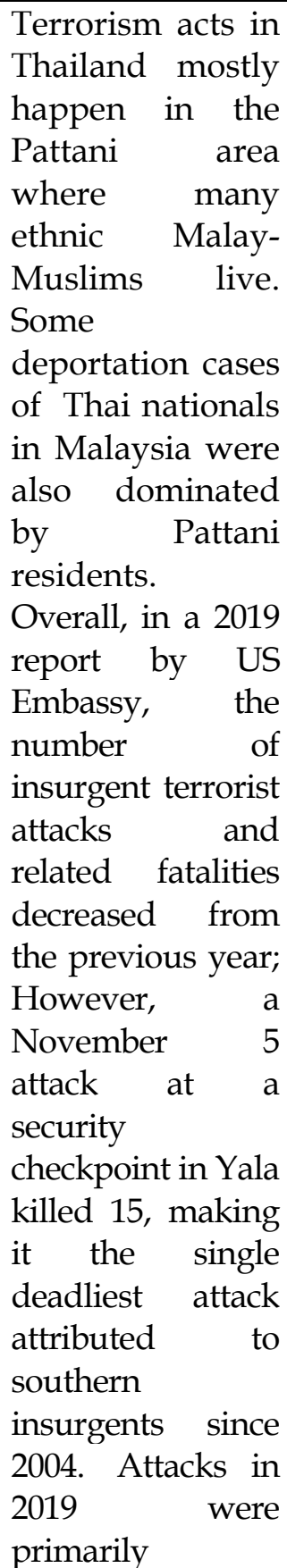 & $\begin{array}{l}\text { The government held a } \\
\text { dialogue with several } \\
\text { institutions, including } \\
\text { those involving BRN } \\
\text { (Barisan Revolusi Nasional), } \\
\text { the National Council for } \\
\text { Peace and Order (NCPO), } \\
\text { and The Majlis Syura } \\
\text { Patani (Patani } \\
\text { Consultative Council, } \\
\text { MARA Patani) }\end{array}$ \\
\hline
\end{tabular}




\begin{tabular}{|c|c|c|c|}
\hline & & $\begin{array}{l}\text { confined to } \\
\text { Thailand's } \\
\text { southernmost } \\
\text { provinces, } \\
\text { although a set of } \\
\text { coordinated } \\
\text { small-scale } \\
\text { explosions in } \\
\text { Bangkok in } \\
\text { August is widely } \\
\text { believed to be } \\
\text { linked to the Deep } \\
\text { South } \\
\text { Insurgency. } \\
\text { Terrorist methods } \\
\text { primarily } \\
\text { included } \\
\text { shootings, arson, } \\
\text { IEDs, } \\
\text { VBIEDs. and }\end{array}$ & \\
\hline Vietnam & $\begin{array}{l}\text { Not yet } \\
\text { found }\end{array}$ & $\begin{array}{l}\text { In 2020, the Ho Ci } \\
\text { Minh City Court } \\
\text { sentenced } 20 \\
\text { people involved in } \\
\text { the terror bombing } \\
\text { of the police } \\
\text { station to } \\
\text { imprisonment. } \\
\text { Terrorism acts in } \\
\text { Vietnam were not } \\
\text { committed by } \\
\text { militants or } \\
\text { terrorist groups } \\
\text { but were triggered } \\
\text { by disappointment } \\
\text { with the } \\
\text { government, } \\
\text { including }\end{array}$ & $\begin{array}{l}\text { Vietnam still relies on the } \\
2009 \text { Penal Code } \\
\text { Amendment to combat } \\
\text { terrorism and emphasizes } \\
\text { criminal justice response to } \\
\text { combat the threat of } \\
\text { terrorism. }\end{array}$ \\
\hline
\end{tabular}




\begin{tabular}{|c|c|c|c|}
\hline & & Communist Party. & \\
\hline $\begin{array}{l}\text { Philipines } \\
\text { (The } \\
\text { National } \\
\text { Counter- } \\
\text { Terrorism } \\
\text { Action Group } \\
\text { (NCTAG) } \\
\text { dan } \\
\text { Anti- } \\
\text { Terrorism } \\
\text { Council) }\end{array}$ & 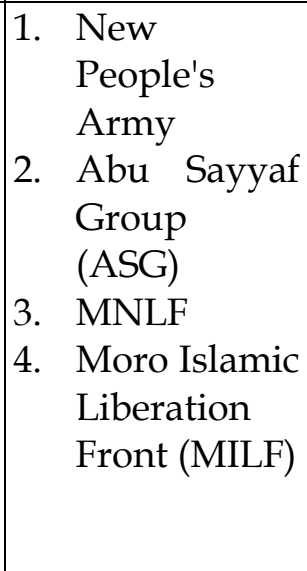 & $\begin{array}{l}2001 \text { killing of } \\
\text { foreign tourists in } \\
\text { Southern } \\
\text { Philippines, } 2001 \\
\text { attack in Manila, } \\
2002 \text { Bombing at } \\
\text { Philippine military } \\
\text { base at Zamoanga, } \\
2003 \text { Bombing at } \\
\text { Davao City } \\
\text { Airport, and 2004 } \\
\text { ferry hijacking }\end{array}$ & $\begin{array}{l}\text { The deployment of US } \\
\text { troops in the Southern } \\
\text { Philippines and adding } \\
\text { funding to tackle terrorism } \\
\text { in Mindanao }\end{array}$ \\
\hline Cambodia & $\begin{array}{ll}\text { 1. } & \text { Khmer } \\
& \text { Rouge rebels } \\
\text { 2. } & \text { Cambodian } \\
& \text { Freedom } \\
& \text { Fighter } \\
& (\mathrm{CFF})\end{array}$ & $\begin{array}{l}\text { Grenade throwing } \\
\text { and establishment } \\
\text { of Cambodian } \\
\text { government } \\
\text { agencies in the } \\
\text { United States }\end{array}$ & $\begin{array}{l}\text { Forming the Royal } \\
\text { Cambodian Army Forces } \\
\text { (RCAF) in collaboration } \\
\text { with the US military in the } \\
\text { form of information and } \\
\text { intelligence sharing, } \\
\text { supervision of financial } \\
\text { transactions, and access to } \\
\text { the use of US aircraft. }\end{array}$ \\
\hline Lao PDR & $\begin{array}{l}\text { 1. Hmong } \\
\text { minority } \\
\text { ethnic } \\
\text { 2. Anti- } \\
\text { communist } \\
\text { in exile } \\
\text { 3. Disaffected } \\
\text { member of } \\
\text { Lao military } \\
\text { 4. Laos } \\
\text { Patriotic } \\
\text { Front (LPF) } \\
\text { 5. Meo } \\
\text { Tribesmen } \\
\text { 6. Ethnic } \\
\text { Liberation }\end{array}$ & $\begin{array}{l}\text { Bombing in public } \\
\text { places and public } \\
\text { facilities since } 2000 \\
\text { and killings aimed } \\
\text { at the Lao } \\
\text { government }\end{array}$ & $\begin{array}{l}\text { Using military force to } \\
\text { oppress ethnic minorities, } \\
\text { such as the Hmong. This } \\
\text { method is deemed useful } \\
\text { enough to narrow the } \\
\text { movement of terrorism in } \\
\text { Laos dominated by ethnic } \\
\text { minorities and factions } \\
\text { expecting to break free } \\
\text { from the sovereign Laos } \\
\text { government. }\end{array}$ \\
\hline
\end{tabular}




\begin{tabular}{|c|c|c|c|}
\hline & $\begin{array}{l}\text { Organization } \\
\text { of Laos } \\
\text { (ELOL) } \\
\text { 7. Laos United } \\
\text { Liberation } \\
\text { Front (LULF) } \\
\text { 8. United } \\
\text { National } \\
\text { Front for } \\
\text { Liberation of } \\
\text { Laos } \\
\text { (LPNLUF) } \\
\text { 9. Lao National } \\
\text { Liberation } \\
\text { Front (LNLF) } \\
\text { 10. Royal Lao } \\
\text { Democratic } \\
\text { Government } \\
\text { (RLDG) }\end{array}$ & & \\
\hline Myanmar & 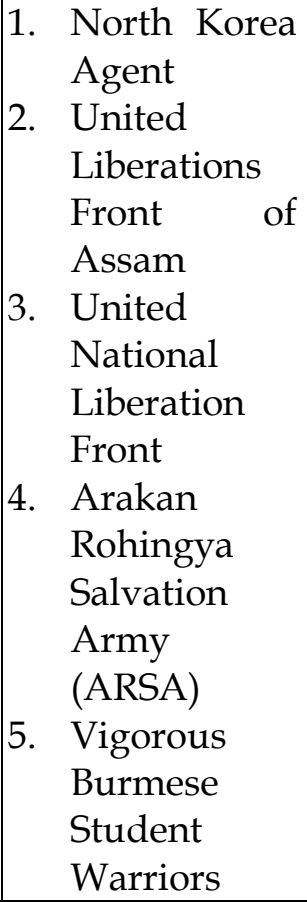 & $\begin{array}{l}\text { Bombing in } \\
\text { Rangoon 1983, in } \\
\text { Yangon } 2005 \text { and } \\
\text { 2010, killings and } \\
\text { ethnic cleansing, } \\
\text { and genocide } \\
\text { against Rohingya } \\
\text { Muslims in } \\
\text { Rakhine, Arakan. }\end{array}$ & $\begin{array}{l}\text { The Myanmar government } \\
\text { establishes the terrorist } \\
\text { label through law. The } \\
\text { terrorist label is attached to } \\
\text { the rebel group. Regarding } \\
\text { the crackdown on terrorism } \\
\text { in Myanmar, the } \\
\text { government uses all forms } \\
\text { of its military power, even } \\
\text { when the cases in the } \\
\text { Rohingya arose. }\end{array}$ \\
\hline
\end{tabular}


The table shows that each ASEAN member country has its own characteristics whether in the model or form of terror they experience, affiliation with terrorist organizations to the prosecution of terrorists or suspected terrorists. Additionally, there are three models of methods or approaches that the ASEAN member countries take in eradicating terrorism, namely: 1) Preventive action in Brunei Darussalam and Vietnam; 2) Repressive action by the police in Indonesia (in an emergency condition, the military will also be accompanied by other elements of the National Armies and State Intelligence Agency like in Malaysia and Singapore; 3) Extra repressive action through full military force in the Philippines, Thailand, Cambodia, Myanmar, and Laos. ${ }^{37}$

The table also implies that the definition of terrorism varies in each country. For example, in Indonesia, JI, JAD, and JAT are referred to as terrorist organizations, while OPM and RMS and their affiliates are only referred to as the Armed Criminal Group (Kelompok Kriminal Bersenjata/KKB). In fact, practically, both JI and OPM use violence and murder while justifying any means to oppose the government. The same thing happens in Myanmar, Laos, Thailand, and the Philippines. The terrorist label is pinned by the state with a variety of legal instruments that the state own. It is prone to be interpreted as an attempt of the state to silence their opponents or opposition while eliminating minorities. In fact, eliminating groups labeled as terrorists potentially violate human rights since it was performed arbitrarily. ${ }^{38}$ Unfortunately, ASEAN countries have made regulations, bodies, or institutions in counter-terrorism actions according to their respective understandings and needs as clear in table 2 below.

\footnotetext{
37 Ong Keng Yong, "Advancing Multilateral Efforts in Counter Terrorism and Security in Southeast Asia," Military Technology 31, no. 12 (2007): 18-23.

38 Achmad Irwan Hamzani et al., "The Trend to Counter Terrorism in Asean," Journal of Advanced Research in Dynamical and Control Systems 12, no. 7 (2020): 105-13, https://doi.org/10.5373/JARDCS/V12I7/20201990. 110
} 
Table 2. Regulations in ASEAN Countries in Combating Terrorism and Its Technical Team ${ }^{39} 40$

\begin{tabular}{|c|c|c|}
\hline No. & Country & Formal Policy \\
\hline 1. & Indonesia & $\begin{array}{l}\text { 1. Instruction of President of the Republic of Indonesia Number } \\
5 \text { the Year } 2002 \\
\text { 2. Law of the Republic of Indonesia Number } 5 \text { the Year } 2018 \\
\text { that amended Law Number } 15 \text { the Year } 2003 \text { concerning the } \\
\text { Establishment of Government Regulation in Lieu of Law } \\
\text { Number } 1 \text { the Year } 2001 \text { concerning the Eradication of } \\
\text { Criminal Acts of Terrorism. } \\
\text { 3. Cooperation with the United States Government. } \\
\text { 4. Attorney General of the Republic of Indonesia } \\
\text { established Terrorism and Transnational Crime Task } \\
\text { Force (TTCTF). } \\
\text { 5. Official Institution built for Counter-Terrorism, such as: } \\
\text { a. Gegana Brimob Detachment } \\
\text { b. Densus } 88 \text { (POLRI or Polisi Republik Indonesia) } \\
\text { c. Counter Terror Desk } \\
\text { d. National Agency for Counter-Terrorism (BNPT; Badan } \\
\text { e. Nasional Penanggulangan Terorisme) } \\
\text { intelligence agency. }\end{array}$ \\
\hline
\end{tabular}

${ }^{39}$ Hamzani et al.

40 Kam, “LAOS.” 


\begin{tabular}{|c|c|c|}
\hline 2. & Thailand & $\begin{array}{l}\text { 1. Supreme Command of the Royal Thai Armed Forces that } \\
\text { move on the operational level of counter-terrorism. } \\
\text { 2. Counter-Terrorism Program by Royal Thai Navy. } \\
\text { 3. The National Security Council (NSC) is led by the Thai } \\
\text { Foreign Ministry. } \\
\text { 4. Thailand Maritime Enforcement Coordination Center (THAI- } \\
\text { MECC). } \\
\text { 5. Martial Law Against Insurgency in Southern Thailand } \\
\text { (Military Emergency and Curfew in Pattani, Yala, and } \\
\text { Narathiwat Areas, 2004). } \\
\text { 6. Expansion of Counter-Terrorism Handling in the financial, } \\
\text { Transnational Corporations/TNC, and drug sectors. }\end{array}$ \\
\hline 3. & Malaysia & $\begin{array}{l}\text { 1. Internal Security Act (ISA). } \\
\text { 2. Penal Code. } \\
\text { 3. Special Motion Regimen under the training of British 22nd } \\
\text { SAS. }\end{array}$ \\
\hline 4. & Myanmar & $\begin{array}{l}\text { 1. Ratification of the ASEAN Convention on Counter-Terrorism } \\
\text { in } 2012 \text {. } \\
\text { 2. The legalization of Strategic Counter-Money Laundering } \\
\text { and Countering the Financing of Terrorism (AML/CFT) } \\
\text { Policy Deficiencies in } 2011 \text {. } \\
\text { 3. The Policy or Law on Counter-Terrorism is still limited to the } \\
\text { Criminal JusticeSystem. }\end{array}$ \\
\hline 5. & Sing & $\begin{array}{l}\text { 1. Internal Security Act. } \\
\text { 2. Singapore Armed Forces Act, forming the special forces of } \\
\text { the Air Marshal Unit. } \\
\text { 3. Police MRT Unit. } \\
\text { 4. Singapore Special Operations Force, Special Operations } \\
\text { Command, Chemical, Biological, Radiological, and } \\
\text { Explosive Defence Group. } \\
\text { 5. Law concerning Money Laundering Elimination/Counter- } \\
\text { Terrorist Financing Regimes. } \\
\text { 6. Military Training with China and the United States. } \\
\text { 7. STEBIS IGM-Indonesia. Deradicalization of Muslim clerics } \\
\text { by empowering the potential of Muslims. }\end{array}$ \\
\hline
\end{tabular}


Satria Unggul Wicaksana Prakasa, Sholahuddin Al-Fatih, Abdurrahman Raden Aji Haqqi

\begin{tabular}{|c|c|c|}
\hline 6. & Philippines & $\begin{array}{l}\text { 1. National Plan to Address Terrorism and its Consequences } \\
\text { (2002). } \\
\text { 2. Autonomous Region of Muslim Mindanao } \\
\text { (ARMM), } \\
\text { 3. Freedom Eagle Operation, } 2002 \text { in the form of the } \\
\text { deployment of U.S. military personnel in the } \\
\text { Southern Philippines. } \\
\text { 4. } \$ 92 \text { million funding support for military assistance in } \\
\text { Mindanao in } 2001 \text {. } \\
\text { 5. A mixed anti-terror Unit between the Armed Forces of the } \\
\text { Philippines and the Philippines National Police. } \\
\text { 6. Establishment of Special Force Regiment to deal with } \\
\text { terrorism. }\end{array}$ \\
\hline 7. & Cambodia & $\begin{array}{l}\text { 1. Cooperation with the UN by Supporting UN Security } \\
\text { Council Resolution Number } 1368 \text { and } 1373 \text { on the War on } \\
\text { International Terrorism. } \\
\text { 2. The formation of Royal Cambodian Army Forces (RCAF) in } \\
\text { cooperation with the United States Military in the form of } \\
\text { information sharing and intelligence, supervision of } \\
\text { financial transactions, and access to the use of United States } \\
\text { aircraft. } \\
\text { 3. The formation of Royal Cambodian Armed Forces '911 } \\
\text { consisting of Commander Battalion. } \\
\text { 4. Ratification of } 4 \text { International Conventions to fight } \\
\text { Terrorism. } \\
\text { 5. Inauguration of the establishment of the secretariat of the } \\
\text { Cambodian National Counter-Terrorism Committee(NCTC). }\end{array}$ \\
\hline 8. & $\begin{array}{l}\text { Brunei } \\
\text { Darussala } \\
\mathrm{m}\end{array}$ & $\begin{array}{l}\text { 1. Anti Terrorism (Financial and other Measures) Act. } \\
\text { 2. Prevention and suppression of terrorist acts. } \\
\text { 3. National security-related program. } \\
\text { 4. Travel and border safety. } \\
\text { 5. Generating awareness. } \\
\text { 6. Cooperation on information exchange. } \\
\text { 7. Biological attack. }\end{array}$ \\
\hline 9. & Vietnam & $\begin{array}{l}\text { 1. Amendment of Penal Code Year } 2009 \text {. } \\
\text { 2. Emphasis on criminal justice response to combat the threat of } \\
\text { terrorism. }\end{array}$ \\
\hline
\end{tabular}




\begin{tabular}{|l|l|l|}
\hline 10. & Laos & $\begin{array}{l}\text { 1. Collaboration with UNODC in } 2012 \\
\text { 2. } \begin{array}{l}\text { Participation in pro-counter terrorism initiatives at a bilateral } \\
\text { level with the US and multilateral level with the UN and } \\
\text { ASEAN } \\
\text { 3ilitary suppression in progress }\end{array}\end{array}$ \\
\hline
\end{tabular}

The differences in regulations and practices of eradicating terrorism shown by countries in ASEAN ultimately provide a clear pattern of response. ASEAN countries have not handled terrorism in the same way. For example, Malaysia and Thailand have relied on more coercive and militaristic responses, whereas Indonesia and Singapore have mostly adopted a non-militaristic, especially law enforcement approach to tackling the problem. ${ }^{41}$ The difference in the pattern of prosecution against terrorism also has an impact on pledging the protection of human rights during the process of combating terrorism in each country. ${ }^{42}$

\section{Human Rights Protection Related to Terrorism in ASEAN}

Human rights are fundamental rights of individuals to be protected and not repressed by the state, since its nativity is based on the Universal Declaration of Human Rights in 1998. Categorically, human rights are divided based on: (1) Civil and political rights as regulated under the International Convention on Civil and Political Rights (ICCPR); (2) Economic, social and cultural Rights regulated under the International Convention on Economy, Social and Cultural

41 See Seng Tan, “After Marawi: Military ' s Regional Role in CounterTerrorism?," RSIS Commentary, no. $016 \quad$ (2018): 2016-18, https://www.rsis.edu.sg/wp-content/uploads/2018/01/CO18016.pdf. 218

42 Ridwan Arifin and Muhamad Adji Rahardian Utama, "Future Impact of the Asean-Russia Law Declaration to the International Terrorism: Can We Combat Terrorist without War?," Russian Law Journal 8, no. 2 (2020): 4-27, https://doi.org/10.17589/2309-8678-2020-8-2-4-27. 23 
Rights (ICESCR), as well as; (3). The rights for development ${ }^{43}$ as the third generation of human rights.

Efforts to protect human rights in the eradication of terrorism are a key issue for the United Nations in establishing standards and mechanisms for combating terrorism. This is as mandated in the Universal Declaration of Human Rights and various derivative Human Rights Covenants. In addition, the acts to avoid repression and extra-judicial killings and to prioritize the due process of law are determinants in the eradication of global terrorism. ${ }^{44}$ Prioritizing the eradication of terrorism with a human rights paradigm is the key to realize human rights protection.

Respect for human rights in ASEAN has become an imperative norm. Furthermore, it has Human Rights Bodies as regulated in Article 14 of the ASEAN Charter. However, the effectiveness of the Agency has not been felt by people of the region, especially victims of terrorism. Likewise, there is a lack of concern about how to get recovered from terrorism with zero loss and victims as well as a little guarantee for a sense of security at a place to live in the area. ${ }^{45}$

In order to conduct equal values in eradicating terrorism and protecting human rights, there are at least four conditions, according to Alex Conte, for ASEAN member countries need to establish and apply: (1). Laws concerning the eradication of terrorism and its full compliance with human rights law; (2). Limited rights and freedoms in terrorism eradication by means of restrictions protected by legal

43 D. Stewart, Terrorism and Human Rights: The Perspective of International Law (Washington DC: Middle East Institute, 2018), https://doi.org/10.2307/resrep19954.7. 112

44 Axel Dreher, Martin Gassebner, and Lars-H. Siemers, "Does Terrorism Threaten Human Rights? Evidence from Panel Data," Journal of Law E Economics 53, no. 1 (2010): 65-93, https://doi.org/10.1086/596021. 68

45 Victor Asal, K Deloughery, and A Murdie, "Responding to Terrorism? Human Rights Organization Shaming and Terrorist Attacks," Studies in Conflict E Terrorism 39, no. 3 (2016): 240-59, https:/ / doi.org/10.1080/1057610X.2015.1093887. 245 
norms; (3). Legislation concerning terrorism eradication and its practice prioritizing legal processes; (4). Legislation concerning terrorism eradication with the right to consider human rights depending on the factual situation and conditions; (5) Legislation concerning terrorism eradication in terms of restricting human rights with proportional enforcement. ${ }^{46}$

Currently, ASEAN had already worked on the ASEAN InterGovernmental Commission on Human Rights (AICHR) as a body that monitors the implementation of principles on promoting and protecting human rights for all member countries. The establishment of this body is a mandate of The Charter of ASEAN. AICHR is supposed to be a significant carrier for all member countries in order to promote the development of strong human rights and to eradicate terrorism in the region. ${ }^{47}$

Under the Charter of ASEAN mechanism, ASEAN member countries agreed on the ASEAN Convention on Counter Terrorism (ACCT) which was signed in Cebu, the Philippines in 2007. At the regional agreement agenda, it has been agreed for cooperative means among ASEAN member countries to (a). take strategic steps to prevent terrorism act, including the exchange of information; (b). discontinue funding, plans, and facilities that support terrorist activities in the region; (c). hinder the movement of terrorist groups through effective border surveillance, including the identification of travel documents held through the Foreign Terrorism Fighters (FTF) mechanism; (d). build capacity and cooperative techniques among member countries to counter terrorism; (e). promote public awareness

46 A. Conte, Handbook on Human Rights Compliance While Countering Terrorism (London: Global Center on Cooperative Security, 2008), https://doi.org/10.2307/resrep20370. 78

47 Abubakar Eby Hara, "The Struggle to Uphold a Regional Human Rights Regime: The Winding Role of Asean Intergovernmental Commission on Human Rights (AICHR)," Revista Brasileira de Politica Internacional 62, no. 1 (2019), https://doi.org/10.1590/0034-7329201900111. 54. 
in terrorism eradication in the region through peace dialogue; (f). enhance the strategy to guard the border areas both land and sea; (g). increase intelligence activities, exchange and sharing information among member countries; (h). increase cooperative activities among member countries by enhancing the database of terrorism groups through ASEAN's special agency appointed by the parties; (i). strengthen the capacity of the state in anticipating the use of chemical, biological, radiological, and nuclear (CBRN) weapons, cyber terrorism, and various developed models; (k). build research capacity related to counterterrorism; (l). utilize video conferences and teleconferences for prosecution; $(\mathrm{m})$. ensure that parties suspected of being actively involved in terrorism crimes have access to justice under the law.

The issue of eradicating terrorism in the region does not only stop at regional agreements but also relates to efforts to build political commitment. ${ }^{48}$ This eradication continues to build an integrated culture among ASEAN member countries in the context of building a stronger commitment to eradicate terrorism. ${ }^{49}$ However, exclusive perspectives and reluctance to cooperate on the grounds of defending national sovereignty and jurisdiction often become common obstacles. In fact, an open and inclusive paradigm in political security matters and is a priority to carry out immediately. ${ }^{50}$

48 Niklas Swanström, "Southeast Asia's War on Terror: Who Is Cooperating across Borders?," Harvard Asia Quarterly 9, no. 1 (2005), https:/ / web.a.ebscohost.com/abstract?direct=true\&profile=ehost\&scope=site\&autht ype $=$ crawler \&jrnl $=15224147 \& A N=18820016 \& h=081 b 27$ VqaImHxUMzj5qWG1GiEPak NbFiByGFsKUmrj5yzqlxAkef5Y1LBAd4F\%2B90RCPbCrliNidmEFXanZPG4Q\%3D\%3 D\&crl=c\&resultNs=AdminWebAuth\&resultLocal=E. 65 .

49 A. Acharya, Constructing a Security Community in Southeast Asia: Asean and the Problem of Regional Order (ProQuest Ebook Central, 2014). 98.

50 Rizal Sukma, "The ASEAN Political and Security Community (APSC): Opportunities and Constraints for the R2P in Southeast Asia," The Pacific Review 25, no. 1 (2012), https:/ / doi.org/10.1080/09512748.2011.632975. 43. 


\section{Conclusion}

Barriers among ASEAN member countries in eradicating terrorism on the pretext of sovereignty and exclusive jurisdiction need to be taken down by establishing defense alliances so that regional solidity and security integrity will increase. In addition, awareness and willingness to integrate criminal policies, the unification of criminal acts of terrorism court, and prosecution by law enforcers among member countries that exceed the jurisdiction of the state (beyond the national jurisdiction) are essential. More importantly, it is vital to ensure that human rights are not violated in the eradication of terrorism. The implementation of counterterrorism should also guarantee the security and peace of civil society, promote law enforcement, and give access to justice for victims of terrorism. Sharpening the effectiveness of Human Rights Bodies' role in ASEAN as a regional body that guarantees the eradication of terrorism is compulsory to protect human rights in Southeast Asia.

\section{Bibliography}

Acharya, A. Constructing a Security Community in Southeast Asia : Asean and the Problem of Regional Order. ProQuest Ebook Central, 2014.

Al-Fatih, Sholahuddin, and Zaka Firma Aditya. "The Legal Protection Against Terrorism Suspects In Indonesia (Case Study of The Arrest Process of Terrorism Suspects By Densus 88)." Legality: Jurnal Ilmiah Hukum 27, no. 1 (2019): 14-26. https://doi.org/10.22219/jihl.v27i1.8954.

Alam, Cecep Purnama. “Tinjauan Yuridis Teori Hak Asasi Manusia Terhadap Tindakan Ekstra Judicial Killing (Studi Kasus Pembunuhan Terduga Teroris Siyono Oleh Densus 88)." Universitas Islam Negeri Syarif Hidayatullah Jakarta, 2019. http:// repository.uinjkt.ac.id/dspace/handle/123456789/480 79.

Arianta, Ketut, Dewa Gede Sudika Mangku, Ni Putu, and Rai Yuliartini. "Perlindungan Hukum Bagi Kaum Etnis Rohingya Dalam Perspektif Hak Asasi Manusia Internasional." Journal Komunitas Yustitia 3, no. 2 (2020): 166-76. https://doi.org/10.23887/jatayu.v3i2.28849.

Arifin, Ridwan, and Muhamad Adji Rahardian Utama. "Future 
Impact of the Asean-Russia Law Declaration to the International Terrorism: Can We Combat Terrorist without War?" Russian Law Journal 8, no. 2 (2020): 4-27. https:/ / doi.org/10.17589/2309-8678-2020-8-2-4-27.

Arnold, Roberta, and Noelle Quenivet. International Humanitarian Law and Human Rights Law: Towards a New Merger in International Law. Leiden and Boston: Martinus Nijhoff Publisher, 2008.

Asal, Victor, K Deloughery, and A Murdie. "Responding to Terrorism? Human Rights Organization Shaming and Terrorist Attacks." Studies in Conflict $\mathcal{E}$ Terrorism 39, no. 3 (2016):

240-59. https://doi.org/10.1080/1057610X.2015.1093887.

Ashour, Omar. The De-Radicalization of Jihadists: Transforming Armed Islamist Movements. 1st ed. London: Routledge, 2009. https:/ / books.google.co.id/books?hl=id\&lr=\&id=h6pTaBDyb KAC\&oi=fnd\&pg=PP1\&dq=Ashour,+ O.+(2009).+The+DeRadicalization+of+Jihadists:+Transforming+Armed+Islamist+ Movements $+(1 \mathrm{st}+\mathrm{ed}) .$.+ Routledge\&ots $=\mathrm{W} 9 \mathrm{r} 2 \mathrm{SjF} 2 \mathrm{v} 2 \& \operatorname{sig}=\mathrm{Nuh}$ X1bzOPZoTLu6iPSAEU0jjBkQ\&redir_esc=y\#v=onep.

Basu, A. "Social Network Analysis: A Methodology for Studying Terrorism." In Intelligent Systems Reference Library, 65:215-42. Basel: Springer Nature, 2014.

Borelli, Marguerite. "ASEAN Counter - Terrorism Weaknesses." International Centre for Political Violence and Terrorism Research 9, no. 9 (2017): 14-20. https://www.jstor.org/stable/pdf/26351552.pdf?refreqid=exc elsior\%3A4b7501f4cc5772d930ea229e7b1c942d.

BUREAU OF COUNTERTERRORISM. "Country Reports on Terrorism 2019: Thailand." US Depratment of State, 2020.

Chau, Andrew. "Security Community and Southeast Asia: Australia, the U.S., and ASEAN's Counter-Terror Strategy." Asian Survey 48, no. 4 (2008): 626-649. https://doi.org/10.1525/as.2008.48.4.626.

Chongkittavorn, Kavi. "Thailand: International Terrorism and the Muslim South." Southeast Asian Affairs, 2004, 267-75.

Chow, Jonathan T. "ASEAN Counterterrorism Cooperation Since 9/11." Asian Survey 45, no. 2 (2005). https://doi.org/https://doi.org/10.1525/as.2005.45.2.302. 
Conte, A. Handbook on Human Rights Compliance While Countering Terrorism. London: Global Center on Cooperative Security, 2008. https://doi.org/10.2307/resrep20370.

Dewi, Asrieyani. "Peran Office Of The High Commissioner For Human Right Dalam Penyelesaian Kasus Genosida Etnis Rohingya Di Myanmar." E-Journal Hubungan Internasional 1, no. 2 (2013).

Dreher, Axel, Martin Gassebner, and Lars-H. Siemers. "Does Terrorism Threaten Human Rights? Evidence from Panel Data." Journal of Law \& Economics 53, no. 1 (2010): 65-93. https://doi.org/10.1086/596021.

Fadila, Ika. "Pelanggaran Hak Asasi Manusia Oleh Densus 88 Dalam Kasus Terduga Terorisme Siyono." UIN SYarif Hidayatullah Jakarta, 2018. http:// repository.uinjkt.ac.id/dspace/handle/123456789/446 29.

Febrica, Senia. "Securing the Sulu-Sulawesi Seas from Maritime Terrorism: A Troublesome Cooperation?" Perspectives on Terrorism 8, no. 3 (2014): 64-83. https://www.jstor.org/stable/26297173?seq=1\#metadata_info _tab_contents.

Frías, Ana María Salinas de, Katja Samuel, and Nigel White. CounterTerrorism: International Law and Practice. Oxford: Oxford University Press, 2012. https:/ / books.google.co.id/books?hl=id\&lr=\&id=mhC7TNrT GmcC\&oi=fnd\&pg=PP1\&dq=Nigel+D.+White, + e.+(2012).+Co unter-

Terrorism:+International+Law+and+Practice.+Oxford:+Oxfor $\mathrm{d}+$ University+Press.\&ots=DUQGBEL00K\&sig=Oh7MYPm239 TK9nn4b1CQ0UpSFRY\&redir_esc=y\#v=onepage.

Gordon, Sandy. "Regionalism and Cross-Border Cooperation against Crime and Terrorism in the Asia-Pacific." Security Challenges 5, no. 4 (2009): 75-102. https://www.jstor.org/stable/26460070?seq=1\#metadata_info _tab_contents.

Gunawan, Asril. “Tinjauan Hukum Internasional Terhadap Pelanggaran Hak Asasi Manusia Dalam Kejahatan Genosida Suku Rohingya Di Myanmar." Universitas Sumatera Utara, 
2018. http://repositori.usu.ac.id/handle/123456789/4479.

Haacke, Juurgen, and Noel M. Morada. Cooperative Security in the AsiaPacific: The ASEAN Regional Forum. New York: Routledge, 2010

Hamzani, Achmad Irwan, Fajar Dian Aryani, Nur Khasanah, Havis Aravik, and Nur Rohim Yunus. "The Trend to Counter Terrorism in Asean." Journal of Advanced Research in Dynamical and Control Systems 12, no. 7 (2020): 105-13. https://doi.org/10.5373/JARDCS/V12I7/20201990.

Hara, Abubakar Eby. "The Struggle to Uphold a Regional Human Rights Regime: The Winding Role of Asean Intergovernmental Commission on Human Rights (AICHR)." Revista Brasileira de Politica Internacional 62, no. 1 (2019). https:/ / doi.org/10.1590/0034-7329201900111.

Haryadi, Dwi. "Pemberantasan Terorisme Berorientasi HAM." Masalah-Masalah Hukum 43, no. 2 (2014): 247-254-254. https://doi.org/10.14710/mmh.43.2.2014.247-254.

Hoffman, P. "Human Rights and Terrorism." Human Rights Quarterly 26, no. 4 (2004): 932-55. www.jstor.org/stable/20069768.

ICG. "Jihadism in Southern Thailand: A Phantom Menace." International Crisis Group, 2017. https://www.crisisgroup.org/asia/south-eastasia/thailand/291-jihadism-southern-thailand-phantommenace.

Indonesia, CNN. "Pemerintah Putuskan Tak Akan Pulangkan 689 WNI Eks ISIS. Retrieved from CNN Indonesia." CNN Indonesia, 2020.

Irwansyah. Penelitian Hukum: Pilihan Metode \& Praktik Penulisan Artikel. Edited by Ahsan Yunus. Yogyakarta: Mirra Buana Media, 2020.

Jerard, Jolene, Ahmad Saiful Rijal bin Hassan, D.B. Subedi, Yanto Chandra, Zoraa Sukabdi, and Muhammad Siaful Alam. Deradicalisation and Terrorist Rehabilitation: A Framework for Policy-Making and Implementation. Edited by Rohan Gunaratna and Sabariah Hussin. Taylor \& Francis, 2018. https:/ / books.google.co.id/books?hl=id\&lr=\&id=7U9tDwAA QBAJ\&oi=fnd\&pg=PT16\&dq=Rohan+Gunaratna,+and+Sabari ah + Hussin $+($ ed $),+$ Deradicalisation+and+Terrorist+Rehabilitati 
on+:+A+Framework+for+Policy-

Making+and+Implementation,+Taylor+\%26+Francis+Group,+ 2018.+ProQu.

Jiménez Ramos, María. "The Impact of the Narrative of Victimization: An Experiment with University Students in Spain." Behavioral Sciences of Terrorism and Political Aggression 0, no. 0 (2020): 1-23. https://doi.org/10.1080/19434472.2020.1856168.

Jins, Derek, and Jackson N. Maogoto. Applying International Humanitarian Law in Judicial and Quasi-Judicial Bodies: International and Domestic Aspects. Edited by Solon Solomon. Springer, 2014. https:/ / books.google.co.id/books?hl=id\&lr=\&id=8fosBAAAQ BAJ\&oi=fnd\&pg=PP5\&dq=Derek+Jins, + e. $+(2008) .+$ Applying + International+Humanitarian+Law+in+Judicial+and+QuasiJudicial+Bodie \%3B+International+and+domestic+aspect.+Lon don:+Springer.\&ots=2GY9Zlh3hK\&sig=rGP6.

Jones, L. ASEAN, Sovereignty, and Intervention in Southeast Asia. London: Palgrave Macmillan, 2011. https:/ / books.google.co.id/books?hl=id\&lr=\&id=DbKIGm7x6 $4 \mathrm{kC} \&$ oi $=$ fnd \&pg $=$ PP1\&dq=Jones,+ L.+(2012).+ASEAN,+ Sovere ignty,+and+Intervention+in+Southeast+Asia.+London:+Palgr ave+MacMillan\&ots=Cr4M8e9lp-\&sig=kCdXruKIq4-

FA8q4qKPLFPPy86A\&redir_esc=y\#v=onepage\&q=Jones $\% 252$.

Kam, Stefanie. "LAOS." In Handbook of Terrorism in the Asia-Pacific, 71-

84. Singapore: Nanyang Technological University, 2016. https://doi.org/10.1142/9781783269969_0004.

Masuhara, A. The SAGE Handbook of Asian Foreign Policy. Edited by Takeshi Inoguchi. California: SAGE Publications, 2020. https://doi.org/10.4135/9781526436078.n54.

Nations, United. UN Doc A/RES/60/1 (2005).

- - - . UNGA Res 60/288 (2006).

Nugraha, AA Bagus Surya Widya. "Singapura Dan Permasalahan Terorisme." Denpasar, 2018. http:// erepo.unud.ac.id/id/eprint/21968/1/258d9fcbf781b6a f3cf5bfb9b1fcdce5.pdf.

Prakasa, Satria Unggul Wicaksana, Basuki Babussalam, and Agus Supriyo. "Transnational Corruption and Its Impact on Indonesian Jurisdiction." In 2nd International Conference of Law, 
Government and Social Justice (ICOLGAS 2020), 43-53. Atlantis Press, 2020. https:/ / doi.org/10.2991/assehr.k.201209.266.

Putra, Aditya, and Diana Lukitasari. "Perbandingan Pengaturan Tindak Pidana Terorisme Di Indonesia Dan Malaysia." Recidivie $8, \quad$ no. 1 (2019): $1-12$. https://jurnal.uns.ac.id/recidive/article/view/40611.

Rachma, Alfianti Dwi. "Perbandingan Hukum Pidana Terhadap Kejahatan Terorisme Di Indonesia Dan Filipina." Universitas Pancasakti Tegal, 2020.

Roach, K. Comparative Counter-Terrorism Law. New York: Cambridge University Press, 2015.

Schmid, A. P. "The Literature on Terrorism." In The Routledge Handbook of Terrorism Research, 460-62. New York: Routledge, 2011.

Sebastian, Leonard C. "The ASEAN Respond to Terrorism." UNISCI Discussion PapersSCI Discussion Paper 2 (2003): 1-8. https://www.redalyc.org/pdf/767/76711296010.pdf.

Staff, Reuters. "Vietnam Jails 20 for Terrorism over Police Station Bombs." Reuters, 2020.

Stewart, D. Terrorism and Human Rights: The Perspective of International Law. Washington DC: Middle East Institute, 2018. https:/ / doi.org/10.2307/resrep19954.7.

Sukma, Rizal. "The ASEAN Political and Security Community (APSC): Opportunities and Constraints for the R2P in Southeast Asia." The Pacific Review 25, no. 1 (2012). https://doi.org/10.1080/09512748.2011.632975.

Susilo, Sulistiyono, and Reza Pahlevi Dalimunthe. "Moderate Southeast Asian Islamic Education as a Parent Culture in Deradicalization: Urgencies, Strategies, and Challenges." Religions 10, no. 1 (2019). https:/ / doi.org/10.3390/rel10010045.

Swanström, Niklas. "Southeast Asia's War on Terror: Who Is Cooperating across Borders?" Harvard Asia Quarterly 9, no. 1 (2005).

https:/ / web.a.ebscohost.com/abstract?direct=true\&profile=eh ost\&scope $=$ site\&authty pe $=$ crawler $\& j \mathrm{rnl}=15224147 \& A N=18820$ 016\&h=O8lb27VqaImHxUMzj5qWG1GiEPakNbFiByGFsKUm rj5yzqlxAkef5Y1LBAd4F\%2B90RCPbCrliNidmEFXanZPG4Q\% 3D\%3D\&crl=c\&resultNs=AdminWebAuth\&resultLocal=E. 
Tan, See Seng. “After Marawi : Military' s Regional Role in CounterTerrorism?" RSIS Commentary, no. 016 (2018): 2016-18. https://www.rsis.edu.sg/wpcontent/uploads/2018/01/CO18016.pdf.

Thontowi, Jawahir. “HAM Di Negara-Negara Muslim Dan Realitas Perang Melawan Teroris Di Indonesia." Pandecta: Research Law Journal 8, no. 2 (2013). https:// doi.org/10.15294/pandecta.v8i2.2680.

Yong, Ong Keng. "Advancing Multilateral Efforts in Counter Terrorism and Security in Southeast Asia." Military Technology 31, no. 12 (2007): 18-23. 